\title{
AKIBAT HUKUM MALPRAKTIK TERHADAP DOKTER DITINJAU DARI HUKUM PERDATA
}

\author{
Mutia Sezia Nur Aini \\ E-mail:mutia.msna@gmail.com \\ Mahasiswa Fakultas Hukum Universitas Sebelas Maret \\ Arief Suryono \\ E-mail: ariefsuryono@staff.uns.ac.id \\ Dosen Fakultas Hukum Universitas Sebelas Maret
}

\begin{abstract}
The aim of this study is to find out the consequence of doing malpractice by a doctor. This case is examined by terms of civil law. This legal study ia a prescriptive normative legal study which uses statute approach. The legal materials used in this study are primary and secondary legal sources. The data collecting technique used in this research is literature studies and document studies. The data are analyzed by deductive method, according to this study, basically the objective of civil liability is to get compensation for patient's losses caused by the breach of contract and or unlawful action of the doctor. The breach of contract done by doctor is the unfulfilled requirements in agreed agreement. By the act against the law, the doctor can be blamed for breakin article 1365, 1367 of Civil Law. Therefore, the doctor should be responsible for compensation either materally or immaterially to the patient or family for error that cause injury and even death.
\end{abstract}

Keywords: Malpractice; Doctor; Breach of Contract; Unlawful Act.

\begin{abstract}
Abstrak
Artikel ini bertujuan untuk mengetahui akibat hukum dokter apabila melakukan malpraktik, dalam hukum perdata. Penelitian hukum ini termasuk jenis penelitian hukum normatif yang bersifat preskriptif, dengan menggunakan pendekatan Peraturan Perundang-undangan. Sumber bahan hukum yang digunakan ialah bahan hukum primer dan sekunder. Teknik pengumpulan data berupa studi kepustakaan atau studi dokumen, dengan menggunakan metode deduktif sebagai teknik analisis. Berdasarkan hasil penelitian, maka pertanggungjawaban perdata pada dasarnya bertujuan memperoleh ganti rugi yang di derita oleh pasien karena adanya wanprestasi dan/perbuatan melanggar hukum dari tindakan dokter. Wanprestasi yang dilakukan dokter adalah dengan tidak memenuhinya syarat yang tertera dalam perjanjian yang telah disepakati. Sedangkan dalam perbuatan melanggar hukum, dokter dapat dipersalahkan apabila melanggar pasal 1365, 1367 Kitab Undang-undang Hukum Perdata. Oleh karena itu, dokter harus bertanggung jawab atas perbuatannya berupa pengganti kerugian baik materiil maupun immateriil terhadap pasien atau keluarga atas kesalahan atau kelalaian yang mengakibatkan pasien cidera atau bahkan meninggal dunia.
\end{abstract}

Kata Kunci: Malpraktik; Dokter; Wanprestasi; Perbuatan Melawan Hukum

\section{A. Pendahuluan}

Dalam kehidupan, kesehatan merupakan hal yang sangat penting. Sebagaimana WHO mengatakan: "health is not everything but without health, everything is nothing" merupakan refleksi kehidupan nyata. Sewaktu kesehatan terganggu atau sakit, akan terasa bahwa segala sesuatunya menjadi tak berarti apa-apa (Sarsintorini Putra, 2003:3). Oleh karena itu, apabila seseorang merasakan sakit maka ia akan segera menghubungi dokter untuk menyembuhkan penyakitnya.

Dalam melaksanakan kewajibannya, dokter bisa saja melakukan kesalahan atau kelalaian ketika menjalankan profesinya yang disebut dengan istilah malpraktik. Malpraktik dapat dilakukan 
baik secara sadar maupun tidak sadar, baik di profesi kedokteran, maupun di seluruh profesi. Malpraktik paling populer di masyarakat adalah malpraktik kedokteran. Dalam pandangan masyarakat, bahwa setiap praktik atau pekerjaan profesional dokter yang menimbulkan kerugian, seolah-olah dokter tetap bersalah, tanpa menilai begaimana faktor subjektif (batin) dokter yang mempengaruhi perbuatan. Padahal pandangan malpraktik kedokteran tidak dapat sekadar hanya menilai wujud perbuatan dokter dan akibatnya tanpa menilai unsur dari sikap batin pelakunya. (Adami Chazawi, 2016:2)

Pandangan malpraktik kedokteran yang dikaitkan pada faktor tanpa wewenang atau tanpa kompetensi dapat diterima dari sudut hukum administrasi kedokteran. Kenyataan pelanggaran yang dilakukan dokter seperti tidak memiliki Surat Izin Praktik (SIP) atau tidak memiliki Surat Tanda Regitrasi (STR), dan lain sebagainya, pada dasarnya merupakan pelanggaran hukum adminitrasi. (Undang-Undang No. 29 Tahun 2004 tentang Praktik Kedokteran, Pasal 36 dan Pasal 29 ayat (1)).

Meskipun praktik dokter yang melanggar hukum administrasi kedokteran dapat dipidana, tapi hal itu bukan termasuk malpraktik kedokteran. Namun pelanggaran semacam itu tetap berpotensi menimbulkan malpraktik kedokteran. Karena pelanggaran administrasi kedokteran merupakan salah satu tempat/letak sifat melawan hukumnya malpraktik kedokteran. Pelanggaran hukum administrasi dapat dianggap sebagai salah satu pintu masuk malpraktik kedokteran. Pelanggaran hukum administrasi kedokteran dapat menjadi malpraktik apabila perlakuan medis dokter menimbulkan kerugian fisik, kesehatan atau nyawa pasien.

Berbeda dari pandangan umum masyarakat bahwa penilaian terhadap perbuatan dokter dimulai dari akibat atau bertitik tolak pada akibat. Namun, pandangan ini melebihi dari arti bahasa tadi, dimana dalam sudut pandang harfiah semata-mata bertitik tolak dari perbuatan yang buruk (mal atau mala). Sementara masyarakat melihatnya dari segi akibatnya yang buruk, barulah menilai pada wujud medis dokter. Oleh karena itu hal itu merupakan akibat buruk, maka perbuatan dokter yang menghasilkan akibat itu menjadi perbuatan buruk (tercela). (Adami Chazami, 2016:3)

Pandangan malpraktik kedokteran juga dapat dilihat dari sudut kewajiban dokter yang dilanggar, dimana tidak adanya malpraktik kedokteran tanpa ada pelanggaran terhadap kewajiban hukum yang diemban dokter dalam hubungan dokter-pasien. Pandangan ini benar, karena tidak mungkin ada malpraktik kedokteran apabila tidak dalam hubungan dokter-pasien, yang artinya ada hubungan hak dan kewajiban antara dokter pasien dalam kontrak terapeutik dimana kemudian hukum dokter itu dilanggar. (Adami Chazawi, 2016:3)

Undang-Undang Nomor 29 Tahun 2004 tentang Praktik Kedokteran tidak memuat ketentuan mengenai malpraktik kedokteran. Pasal 66 ayat (1) memuat kalimat yang mengarah pada kesalahan praktik dokter, yaitu: "Setiap orang yang mengetahui atau kepentingannya dirugikan atas tindakan dokter atau dokter gigi dalam menjalankan praktik kedokteran dapat mengadukan secara tertulis kepada Ketua Majelis Kehormatan Disiplin Kedokteran Indonesia". Namun dalam norma tersebut hanya memberi dasar hukum untuk melaporkan dokter ke organisasi profesinya apabila terdapat indikasi tindakan dokter membawa kerugian. Pasal itu hanya mempunyai arti dari sudut pandang hukum administrasi kedokteran.

Pasal 58 ayat (1) Undang-Undang Nomor 36 Tahun 2009 tentang Kesehatan merumuskan kalimat yang lebih jelas tentang hak pasien menuntut ganti kerugian akibat kesalahan atau kelalaian dalam pelayanan kesehatan yang diterimanya, tetapi tidak dijelaskan apa arti isinya sehingga kriteria kesalahan atau kelalaian dalam pelayanan kesehatan tetap tidak jelas.

Ketentuan serupa juga terdapat dalam Pasal 77 Undang-Undang Nomor 36 Tahun 2014 tentang Tenaga Kesehatan yang menyatakan bahwa: "Setiap penerima pelayanan kesehatan yang dirugikan akibat kesalahan atau kelalaian tenaga kesehatan dapat meminta ganti rugi sesuai dengan ketentuan peraturan perundang-undangan". Setiap akan dilakukannya pelayanan kesehatan, maka dibutuhkan persetujuan dari pasien untuk diperiksa oleh dokter. Dalam hal ini akan menimbulkan hubungan hukum antara dokter dan pasien yang dilaksanakan dengan rasa kepercayaan dari pasien terhadap dokter yang disebut dengan istilah transaksi terapeutik. 
Berdasarkan latar belakang di atas, maka penulis tertarik mengkaji lebih dalam tentang akibat hukum malpraktik terhadap dokter dalam perspektif hukum perdata.

\section{B. Metode Penelitian}

Penelitian ini adalah penelitan hukum normatif. Yaitu penelitian yang mengkaji bahan-bahan hukum primer yang bersifat mengikat perundang-undangan sebagai hukum positif di Indonesia seperti buku literature, jurnal, hasil penelitian ilmiah lainnya yang berhubungan dengan penelitian ini. (Peter Mahmud Marzuki, 2005:133)

Penelitian ini merupakan penelitan hukum normative yang bersifat preskriptif. Pendekatan yang digunakan adalah pendekatan peraturan perundang-undangan (statute approach). Teknik pengumpulan bahan hukum adalah studi kepustakaan atau studi dokumen. Penulisan hukum ini menggunakan teknik analisis bahan hukum dengan metode silogisme melalui pola pemikiran deduktif. Penggunaan pola berfikir deduktif berpangkal dari premis mayor yang merupakan aturan hukum.

\section{Hasil Penelitian dan Pembahasan}

Malpraktik adalah suatu istilah yang memiliki arti konotasi yang buruk, bersifat stigmatis serta menyalahkan. Ada beberapa pendapat yang menyatakan bahwa malpraktik sama dengan kelalaian, karena kesulitan untuk menemukan perbedaannya. Menurut J. Guwandi dalam bukunya Hukum Medik, malpraktik tidak sama dengan kelalaian. Karena malpraktik memiliki arti yang lebih luas dari kelalaian. Kelalaian memang masuk dalam arti malpraktik, namun malpraktik tidak selalu harus ada unsur kelalaian. Istilah malpraktik dapat mencakup tindakan-tindakan yang dilakukan dengan sengaja dan melanggar peraturan perundang-undangan. Arti sengaja tersirat adanya motif di dalamnya. Sedangkan kelalaian lebih kepada ketidaksengajaan, kurang teliti, kurang hati-hati, ceroboh sembrono dan tidak peduli terhadap kepentingan orang lain. Namun dapat berakibatkan melenceng dari apa yang menjadi tujuannya. (J. Guwandi, 2005: 20-21)

Kesalahan dokter timbul sebagai akibat terjadinya tindakan yang tidak sesuai, atau tidak memenuhinya prosedur medis yang seharusnya dilakukan. Kesalahan seperti itu kemungkinan dapat terjadi karena faktor kesengajaan atau kelalaian dari seorang dokter. Kesalahan selalu ditunjukkan pada perbuatan yang tidak patut, yaitu melakukan sesuatu yang seharusnya tidak dilakukan dan atau tidak melakukan sesuatu yang seharusnya mesti dilakukan. Kesalahan yang dilakukan oleh dokter apabila terjadi karena kurangnya pengetahuan, kurangnya pengalaman, dan atau kurangnya kehati-hatian.

Sedangkan kelalaian dapat dikatakan merupakan salah satu kesalahan yang timbul karena pelakunya tidak memenuhi standar perilaku yang telah ditentukan. Kelalaian ini timbul karena faktor orangnya atau pelakunya. Dalam pelayanan kesehatan faktor penyebab timbulnya kelalaian adalah karena kurangnya pengetahuan, kurangnya kesungguhan serta kurangnya ketelitian dokter pada waktu melakukan perawatan.

Ada perbedaan yang lebih jelas apabila dilihat dari motif masing-masing. Dimana malpraktik memiliki arti sempit yaitu tindakan yang dilakukan secara sadar, dan tujuan dari tindakannya sudah terarah kepada akibat yang hendak ditimbulkan atau tidak peduli terhadap akibatnya, walaupun sudah diketahui atau seharusnya mengetahui bahwa tindakan tersebut dapat bertentangan dengan hukum yang berlaku. Sedangkan, kelalaian tidak ada motif atau pun tujuan untuk menimbulkan akibat yang terjadi. Akibat yang timbul itu pun disebabkan karena adanya kelalaian yang sebenarnya terjadi di luar kehendak. (J. Guwandi, 2005:21)

Hubungan hukum dalam kontrak terapeutik memuat hak dan kewajiban hukum para pihak. Dilaksanakannya kewajiban hukum dokter selalu dibayangi dengan adanya risiko. Pelayanan dokter bagi pasien dapat membawa kerugian kesehatan dan nyawa. Sedangkan bagi dokter berupa sanksi ringan sampai terberat dengan bersifat moral kemasyarakatan sampai hukum (administrasi, 
perdata dan pidana). Kewajiban pelayanan medis secara umum harus sesuai dengan standar umum kedokteran, standar profesi kedokteran dan standar prosedur operasional. Dilanggarnya standar profesi dan standar prosedur ini merupakan salah satu syarat malpraktik kedokteran.

Standar profesi sebagaimana diatur dalam Pasal 51 huruf a Undang-Undang Nomor 29 Tahun 2004 juncto Pasal 58 ayat (1) huruf a Undang-Undang Nomor 36 Tahun 2014, yang menyatakan bahwa, standar profesi dan standar prosedur operasional adalah norma hukum yang mengikat perbuatannya. Sebagai pembatas agar setiap langkah dokter tidak boleh keluar dan harus sama dengan norma dalam standar profesi dan standar prosedur operasional.

Wanprestasi adalah prestasi yang buruk, dimana salah satu pihak atau debitur melakukan suatu pelanggaran dalam perjanjian/kontrak. Bentuk pelanggaran tersebut adalah: (Adami Chzawi. 2016: 41)

1. Tidak memberikan prestasi sama sekali sebagaimana yang telah diperjanjikan;

2. Memberikan prestasi tidak sebagaimana mestinya, tidak sesuai kualitas atau kuantitas sebagaimana yang diperjanjikan;

3. Memberikan prestasi akan tetapi sudah terlambat, tidak tepat waktu sebagaimana yang diperjanjikan;

4. Memberikan prestasi yang lain dari yang diperjanjikan semula.

Wanprestasi dokter dari perjanjian terapeutik dapat berupa salah satu atau beberapa dari empat macam tersebut. Sebagaimana perjanjian terapeutik yang merupakan inspanningverbintenis, dimana kewajiban atau prestasi dokter yang harus dijalankan pada pasien adalah perlakuan medis yang sebaik-baik dan secermat-cermatnya sesuai dengan standar profesi medis atau standar prosedur operasional. Hal ini menyebabkan wanprestasi dokter paling dekat dengan bentuk pelanggaran kewajiban yang kedua dan keempat. Keadaan wanprestasi dalam malpraktik kedokteran hanya terjadi pelanggaran persetujuan oleh pihak dokter walaupun kewajiban pasien tidak dipenuhi. Namun, tidak dipenuhinya kewajiban pasien, dapat mempengaruhi tanggung jawab dokter baik dari yang berat hingga dapat membebaskan tanggung jawab dokter. Tidak mustahil pelanggaran kewajiban oleh pasien begitu kuat pengaruhnya teradap diagnosis maupun terapi dokter, yang menyebabkan perlakuan medis dokter salah dan menjadi fatal akibatnya.

Kriteria wanprestasi yang dilakukan oleh dokter didasarkan pada Pasal 1238 KUHPerdata dengan istilah singkat ialah debitur dinyatakan lalai karena berdasarkan kekuatan dari perikatan itu sendiri. Yang menjadi isi aspek yang tidak dipenuhinya suatu ikatan tersebut adalah tidak melaksanakan isi perjanjian. Pada dasarnya perjanjian adalah melakukan prestasi, yaitu: berbuat sesuatu, tidak berbuat sesuatu, dan memberikan sesuatu (Pasal 1234 KUHPerdata). Prestasi dokter dalam perjanjian terapeutik adalah prestasi berbuat sesuatu dalam bentuk pelayanan medis pada pasien sesuai dengan standar prosedur operasional dan standar profesi medis, termasuk kebutuhan medis pasien dan kebiasaan umum yang wajar dari sudut disiplin kedokteran. Selain ada pelanggaran terkait isi perjanjian in casu kewajiban melakukan prestasi, dalam setiap wanprestasi terkandung aspek kerugian bagi pihak lain. Unsur kerugian terdapat kalimat "penggantian biaya, rugi dan bunga..." dalam Pasal 1243 KUHPerdata, khususnya pada perkataan rugi yang artinya suatu kerugian. Demikian juga kerugian pasien adalah pangkal tolak dari penilaian terhadap ada atau tidaknya malpraktik kedokteran.

Wujud kerugian dalam wanprestasi pelayanan dokter harus benar-benar akibat (casuaal verband) dari perlakuan medis yang menyalahi standar profesi kedokteran atau standar prosedur operasional. Wujud kerugian akibat wanprestasi (malpraktik kedokteran) hanya berupa kerugian materiil yang dapat diukur dengan nilai uang terutama biaya perawatan, biaya perjalanan, biaya obat-obatan (pengobatan). Kerugian-kerugian ini dapat dituntut oleh pasien atau ahli warisnya pada dokter atau rumah sakit yang melakukan perawatan. Mengenai kerugian ini wajib dibuktikan. Pihak penuntut yang ingin menuntut ganti rugi harus dapat membuktikan adanya empat unsur, yaitu: (Soekidjo Notoatmodjo, 2010:169) 
1. Adanya sebuah kewajiban bagi petugas kesehatan terhadap penderita atau pasien, tetapi tidak dilakukan.

2. Petugas kesehatan telah melanggar standar pelayanan kesehatan (medis) yang lazim digunakan.

3. Penggugat atau penderita dan atau keluarganya telah menderita kerugian yang dapat dimintakan ganti rugi.

4. Secara jelas (factual kerugian itu disebabkan oleh tindakan di bawah standar atau ketentuan profesi kesehatan/medis).

Selain membuktikan perlakuan dokter yang menyimpang dari standar profesi, juga harus dibuktikan kerugian yang diakibatkan dari perlakuan menyimpang dokter itu sendiri. Pada dasarnya perlakuan medis yang menyimpang dari standar profesi dan adanya kerugian adalah unsur kumulatif yang harus ada pada setiap malpraktik kedokteran.

Sementara itu, kerugian immaterial seperti kehilangan harapan kesembuhan, rasa penderitaan atau kesakitan yang berkepanjangan, kehilangan bagian tubuh tertentu, hilang ingatan, hilang penglihatan, luka-luka bahkan sampai pada kematian pasien bukan merupakan kerugian yang dapat dituntut atas dasar wanprestasi, namun dapat dituntut atas dasar perbuatan melawan hukum (onrechtmatige daad) sebagaimana diatur dalam Pasal 1365 KUHPerdata, yang berisikan "Tiap perbuatan melanggar hukum, yang membawa kerugian kepada orang lain, mewajibkan orang yang karena salahnya menimbulkan kerugian itu, untuk mengganti kerugian tersebut".

Perlakuan medis dokter yang menyimpang dari standar prosedur operasional dan standar profesi yang menimbulkan kerugian pada pasien dapat masuk dalan kategori perbuatan melawan hukum menurut pasal 1365 KUHPerdata. Hal ini karena adanya perkataan "...karena salahnya..." dalam rumusan Pasal 1365 KUHPerdata dapat diterapkan pada kasus pelayanan medis yang menyimpang (malpraktik kedokteran). Yang dimaksud dengan "karena salahnya" dapat berbentuk kesalahan ataupun kelalaian dokter baik dalam bentuk hal berbuat (aktif) maupun tidak berbuat (pasif) yang dimana dokter seharusnya dokter berbuat dalam perlakuan medis kepada pasien. Kerugian ini haruslah benar-benar diakibatkan oleh perlakuan medis yang salah, dan harus dibuktikan baik dari sudut ilmu kedokteran dan ilmu hukum.

Pasal 1365 KUHPerdata tidak merumuskan arti dari perbuatan melawan hukum, hanya syaratsyarat yang diperlukan agar gugatan penggantian kerugian karena perbuatan melawan hukum dapat dibenarkan dan dikabulkan. Berdasarkan Putusan Arrest Hoge Raad tanggal 31 Januari 1919 pada perkara Lindenbaum vs. Cohen, Moegni Djojodirdjo mengambil kesimpulan yaitu, ada beberapa syarat dimana suatu perbuatan (daad) apabila memenuhi salah satu atau beberapa, barulah dapat disebut perbuatan melawan hukum, yaitu: (MA. Moegni Djojodirdjo. 1979: 35)

- Bertentangan dengan hak orang lain;

- Bertentangan dengan kewajiban hukumnya sendiri;

- Bertentangan dengaan nilai-nilai/norma kesusilaan;

- Bertentangan dengan keharusan yang harus diindahkan dalam pergaulan masyarakat mengenai orang lain atau benda.

Perbuatan melawan hukum dapat didefinisikan sebagai perbuatan aktif maupun pasif (tidak berbuat padahal seharusnya berbuat) yang dilakukan baik karena kesengajaan maupun kealpaan yang bertentangan dengan nilai-nilai/norma kesusilaan atau dengan keharusan yang harus diindahkan dalam pergaulan masyarakat. Definisi ini juga telah mencakup sebagian syarat menuntut penggantian kerugian oleh perbuatan melawan hukum, yakni harus ada perbuatan (daad) yang bersifat melawan hukum (onrechtmatige).

Berdasarkan pengertian perbuatan melawan hukum dari Pasal 1365 KUHPerdata tersebut, ada 4 syarat yang harus dipenuhi untuk menuntut kerugian adanya perbuatan melawan hukum termasuk malpraktik kedokteran yang masuk kualifikasi perbuatan melawan hukum, yaitu:

1. Adanya perbuatan (daad) yang termasuk kualifikasi perbuatan melawan hukum. 
2. Adanya kesalahan (dolus maupun culpos) si pembuat.

3. Adanya akibat kerugian (schade).

4. Adanya hubungan perbuatan dengan akibat kerugian (casuaal verband) orang lain.

Syarat pertama harus ada perbuatan. Dimana tidak ada perbuatan melawan hukum kalau tidak ada perbuatan (aktif atau pasif) sama sekali. Berbuat sesuatu atau tidak berbuat sesuatu yang diwajibkan, memiliki ukuran sifat melawan hukum yang berbeda-beda, antara lain pada kewajibannya menurut standar profesi dan standar prosedur, kewajaran umum di bidang kedokteran, pada kewajiban menurut hukum, bahkan kesusilaan umum. Sifat melawan hukum dokter dalam melakukan pelayanan medis justru terdapat dalam hal pelanggaran terhadap kewajiban-kewajiban tersebut.

Rumusan Pasal 1365 KUHPerdata terdapat kata "karena salahnya menerbitkan kerugian itu", mengandung makna bahwa kerugian yang diderita orang lain itu baru dapat dibebankan penggantiannya pada pembuat bila terdapat kesalahan (schuld) pada diri orangnya. Syarat ini merupakan dasar pembebanan pertanggungjawaban hukum terhadap kerugian pada si pembuat. Dalam hal ini, tidak cukup sekadar adanya sikap batin yang tercela dalam diri pelaku, namun haruslah telah diwujudkan dalam perbuatan sehingga perbuatannya juga tercela, setidaknya sudah ada permulaan pelaksanaan, meskipun tidak selesai atau delik tidak terwujud sebagaiman semula dikehendaki.

Dalam Pasal 1367 Kitab Undang-Undang Hukum Perdata, seseorang harus memberikan pertanggungjawaban tidak hanya atas kerugian yang ditimbulkan dari tindakan sendiri, tetapi juga atas kerugian yang ditimbulkan dari tindakan orang lain yang berada di bawah pengawasannya. Pada pokok ketentuan Pasal 1367 mengatur tentang pembayaran ganti rugi oleh pihak yang menyuruh atau yang memerintah sesuatu pekerjaan yang mengakibatkan kerugian pada pihak lain tersebut. Berdasarkan Pasal 46 Undang-Undang Nomor 44 Tahun 2009 tentang Rumah Sakit, pihak rumah sakit dalam hal ini direktur rumah sakit bertanggung jawab secara hukum terhadap semua kerugian atas kelalaian yang dilakukan oleh tenaga kesehatan di rumah sakit.

Dalam malpraktik kedokteran yang menjadi perbuatan melawan hukum karena sifatnya maka kehendak sering diarahkan pada wujud perbuatan dan tidak pada akibat. Culpa biasanya hanya tertuju pada akibat. Akibat yang merugikan pasien tidaklah dikehendaki. Dalam malpraktik kedokteran wujud perbuatan harus tidak sesuai dengan standar profesi medis dan standar prosedur operasional atau setidak-tidaknya bertentangan dengan kebiasaan umum yang wajar di dunia kedokteran.

Ada perbedaan kerugian yang dapat dituntut melalui perbuatan melawan hukum dan wanprestasi. Kerugian yang disebabkan adanya wanprestasi yaitu kerugian meteriil, berupa kerugian yang dapat dinilai dengan uang. Sedangkan kerugian yang disebabkan perbuatan melawan hukum selain kerugian materiil, juga kerugian idiil (immaterial) yang tidak bersifat kebendaan, namun dapat diperkirakan nilai kebendaannya berdasarkan kelayakan atau kepatutan.

Nilai kerugian yang dapat dituntut/digugat atas dasar perbuatan melawan hukum tidak ditentukan oleh UU. Penggugat dapat menentukan nilai kerugian idiil maupun materiil atas dasaran taksirannya sendiri. Lalu hakim akan menilai sesuai kelayakan, terutama dalam kerugian idiil. Kerugian macam apa pun yang diakibatkan oleh perbuatan melawan hukum pada dasarnya dapat dituntut, kecuali karena suatu kepentingan yang tidak sah. Begitu pula bagi suatu kerugian dalam pelayanan medis yang tidak semata-mata disebabkan oleh perbuatan dokter, tetapi ada pengaruh kuat dari perbuatan pasien sendiri.

Hubungan kausal hukum perdata digunakan untuk menentukan adanya kerugian oleh suatu perbuatan dalam upaya penggantian kerugian oleh si pembuat yang bersalah. Syarat adanya hubungan kausal antara perbuatan dan kerugian oleh adanya perbuatan melawan hukum menjadi salah satu unsur esensial. Dalam hubungan dokter-pasien, penderitaan fisik maupun psikis pasien baru dapat masuk ranah malpraktik perdata apabila terdapat hubungan kausal antara pelayanan dokter dengan akibat tersebut. 
Setiap pelanggaran (baik etika profesi, atau pelanggaran disiplin profesi, maupun pelanggaran hukum) dapat dilakukan penegakan hukum. Penyelesaian kasus dalam pelayanan kesehatan yang melalui lembaga non-litigasi, salah satunya adalah melalui mediasi. Hal ini diatur dalam UndangUndang Nomor 36 tahun 2009 tentang Kesehatan serta apabila terdapat dugaan kelalaian maka harus diselesaikan melalui jalur mediasi. Mediasi adalah suatu upaya penyelesaian sengketa para pihak dengan kesepakatan bersama melalui mediator yang bersikap netral dan tidak membuat keputusan atau kesimpulan bagi para pihak tetapi menunjang untuk terlaksananya dialog antar pihak dengan suasana keterbukaan, kejujuran dan tukar pendapat untuk tujan tercapainya mufakat.

\section{Simpulan}

Pertanggungjawaban perdata pada dasarnya bertujuan untuk memperoleh ganti rugi yang diderita oleh pasien karena adanya wanprestasi dan/perbuatan melawan hukum dari tindakan dokter. Wanprestasi terjadi apabila dokter tidak memenuhinya perjanjian antara dokter dengan pasien. Hal tersebut dapat mengakibatkan adanya gugatan ganti rugi dari pasien kepada dokter. Dimana dalam gugatan harus dibuktikan bahwa dokter melakukan wanpretasi dan menimbulkan kerugian. Sedangkan dalam perbuatan melawan hukum, dokter dapat dipersalahkan apabila telah terjadi perbuatan melanggar hukum, yang menyebabkan kerugian. Oleh karena itu, seorang dokter harus bertanggung jawab atas kesalahan/kelalaian yang mengakibatkan pasien cidera atau bahkan meninggal dunia. Tanggung jawab berupa pengganti kerugian baik materiil dan immaterial terhadap pasien/keluarga. Penyelesaian sengketa dalam pelayanan kesehatan melalui jalur nonlitigasi dan litigasi

\section{E. Saran}

1. Pihak rumah sakit, dalam hal ini dokter dan tenaga kesehatan, harus mensosialisasikan dan mengingatkan tentang Standar Operasional Prosedur dan Standar Pelayanan Medis yang berlaku kepada dokter dan tenaga kesehatan lainnya yang bertugas di rumah sakit dengan tujuan untuk meminimalisir tuntutan medis maupun sengketa hukum yang berkaitan terhadap malpraktik.

2. Diperlukannya peraturan yang dibuat oleh pemerintah dalam hal ini Menteri Kesehatan atau pihak terkait, mengenai malpraktik secara spesifik dan mendalam agar apabila terjadi sengketa penyelesaiannya sudah diatur dan lebih mudah dalam melakukan penyelesaian sengketa.

\section{Daftar Pustaka}

Adami Chazawi. 2016. Malpraktik Kedokteran. Jakarta: Sinar Grafika.

J. Guwandi. 2005. Medical Error dan Hukum Medis. Jakarta: Balai Penerbit Fakultas Kedokteran Universitas Indonesia.

M.A. Moegni Djojodirdjo. 1979. Perbuatan Melawan Hukum. Jakarta: Pradnya Paramita.

Sarsintorini Putra. 2003. "Prespektif Hukum Kesehatan Indonesia dalam Mewujudkan Derajat Kesehatan Masyarakat yang Optimal". Pidato pengukuhan Guru Besar IImu Hukum. Semarang: Fakultas Hukum UNTAG.

Amanda L. Walter. 2013. "Medical Malpractice and Hernia Reapair: An Analysis of Case Law". Journal of Surgical Research 180. North Carolina: Departement of General Sugery.

Armanda Dian K. 2015. "Urgensi Penerapan Mekanisme Informed Consent untuk Mencegah Tuntutan Malpraktik dalam Perjanjian Terapeutik". Privat Law. Vol. III. Nomor. 2. Surakarta: Bagian Keperdataan Fakultas Hukum UNS.

Rini Dameria. 2017. "Perbuatan Melawan Hukum dalam Tindakan Medis dan Penyelesaiannya di Mahkamah Agung". Dipenogoro Law Journal. Vol 6. Nomor 1. Semarang: Fakultas Hukum UNDIP. 
Venny Sulistyani. 2015. "Pertanggungjawaban Perdata Seorang Dokter dalam Kasus Malpraktik Medis". Lex Jurnalica. Vol. 12. Nomor. 2. Jakarta.

Widodo Tresno Novianto. 2015 "Penafsiran Hukum dalam Menentukan Unsur-Unsur Kelalaian Malpraktik Medik (Medical Malpractice)". Yustisia. Vol. 4. Nomor. 2. Surakarta: Fakultas Hukum UNS.

Undang-Undang Dasar Negara Republik Indonesia Tahun 1945.

Kitab Undang-Undang Hukum Perdata.

Undang-Undang Nomor 29 Tahun 2004 tentang Praktik Kedokteran.

Undang-Undang Nomor 36 Tahun 2009 tentang Kesehatan. 